Portland State University

PDXScholar

Spring 6-4-2019

\title{
An Investigation of the Impact of High School \\ Student Fine Arts Course Accumulation on \\ Mathematics Course Achievement
}

Daniel Mackin Freeman

Portland State University

Follow this and additional works at: https://pdxscholar.library.pdx.edu/open_access_etds

Part of the Art Education Commons, and the Science and Mathematics Education Commons Let us know how access to this document benefits you.

\section{Recommended Citation}

Mackin Freeman, Daniel, "An Investigation of the Impact of High School Student Fine Arts Course Accumulation on Mathematics Course Achievement" (2019). Dissertations and Theses. Paper 5041. https://doi.org/10.15760/etd.6917

This Thesis is brought to you for free and open access. It has been accepted for inclusion in Dissertations and Theses by an authorized administrator of PDXScholar. Please contact us if we can make this document more accessible: pdxscholar@pdx.edu. 
An Investigation of the Impact of High School Student Fine Arts Course Accumulation on Mathematics Course Achievement

\author{
by
}

\title{
Daniel Mackin Freeman
}

A thesis submitted in partial fulfillment of the requirements for the degree of

\author{
Master of Science \\ in \\ Sociology
}

\begin{abstract}
Thesis Committee:
Dara Shifrer, Chair

Lindsey Wilkinson

Julius McGee
\end{abstract}

\section{Portland State University} 2019 
(C) 2019 Daniel Mackin Freeman 


\begin{abstract}
Science, technology, engineering, and mathematics (STEM) educational achievement is vital to economic competitiveness in the United States and abroad. Despite a concerted effort, the US lags well behind many similarly developed nations. Research suggests that the integration of fine arts education into traditional STEM curriculum (STEAM) boosts academic achievement in STEM subjects and closes gaps between low- and high-socioeconomic status students. Justifications for STEAM programs are based, however, on the unexamined assumption, for one, that fine arts courses instill creative and critical thinking skills that can be transferred to STEM subjects. The present study explores the impact of taking fine arts courses on mathematics achievement in high school. Using the High School Longitudinal Study of 2009 and multi-level regression modeling, this study provides evidence that credit accumulation in fine arts courses relates positively to advancing past Algebra II in high school. Additionally, this estimated impact is much greater in magnitude for low-SES students than for their high-SES peers.
\end{abstract}




\section{ACKNOWLEDGEMENTS}

This research was supported by the National Science Foundation (DRL-1652279), principle investigator: Dr. Dara Shifrer. I would also like to acknowledge my advisor Dr. Dara Shifrer for her invaluable guidance and feedback. Additionally, members of the CAREER research team provided a tremendous amount of feedback throughout the process. Finally, I would like to acknowledge my family and especially my incredible partner, Madelyn Mackin Freeman. Your love and support made this possible, thank you. 


\section{TABLE OF CONTENTS}

ABSTRACT

ACKNOWLEDGEMENTS

II

LIST OF TALBES

LIST OF FIGURES

INTRODUCTION

LITERATURE REVIEW

Education, Ideology, and Hegemony 4

From STEM to STEAM: Key Theoretical Assumptions $\quad 7$

Cognitive Transfer, SES, and Empirical Evidence 9

PURPOSE OF THE PRESENT STUDY 12

DATA AND METHODS 13

$\begin{array}{ll}\text { Advanced Past Algebra II (Transcript Data (2014)) } & 14\end{array}$

Credit Accumulation in Fine Arts Education (Transcript Data (2014)) 15

Socioeconomic Status (Wave 1 (2009) Student Data) 15

Student-level Controls (Wave 1 (2009) Data) 16

$\begin{array}{ll}\text { School Characteristics (Wave } 1 \text { (2009) Data) } & 17\end{array}$

iii 
RESULTS

DISCUSSION

REFERENCES 


\section{LIST OF TALBES}

Table 1, Part 1 of 2: Descriptive Statistics

Table 1, Part 2 of 2: Descriptive Statistics

Table 2: Descriptive Statistics Stratified by Socioeconomic Status

Table 3, Part 1 of 2: Log Odds from Multilevel Logistic Regression Models Predicting Advanced Past Algebra II

Table 3, Part 2 of 2: Log Odds from Multilevel Logistic Regression Models Predicting Advanced Past Algebra II 


\section{LIST OF FIGURES}

Figure 1: Predicted Probabilities of Advancing Past Algebra II Depending on Credits Earned in Fine Arts and Socioeconomic Status 


\section{INTRODUCTION}

In the United States and abroad, STEM (science, technology, engineering, and mathematics) education, the precursor to entry into STEM occupations, is a vital component of overall economic competitiveness and national security (Gonzalez and Kuenzi 2012). Furthermore, innovation in STEM occupations is thought to be important to viability and competitiveness in both national and global economic markets (Atkinson and Mayo 2010). Based on the general recognition of the importance of STEM occupations in US competitiveness, the US Department of Education (2017) has clearly stated that access to, and achievement in, STEM fields are the nation's top educational priority.

Despite numerous national education initiatives that prioritize STEM in schools, the US ranks $38^{\text {th }}$ in math and $24^{\text {th }}$ in science in comparison with 71 similarly developed nations (DeSilver 2017). In addition, US mathematics rankings appear to be in decline. Mathematics performance dropped in 2015 for the first time since 1990 (DeSilver 2017), suggesting a need for new approaches to addressing poor mathematics outcomes in the US. Most importantly, a lack of access and poorer academic achievement in STEM subjects disproportionally affects low-socioeconomic status (SES) students (Blums et al. 2017; Gonzalez and Kuenzi 2012). Because success in STEM education leads to higher levels of employability in high-paying, high-status, and in-demand occupations, gaps in achievement and unequal representation in STEM education between lower- and higherSES echelons contribute to the reproduction of social inequality in the US (Melguizo and Wolniak 2012). Additionally, workers' ability to take innovative approaches to STEM 
occupations is increasingly important to employability within those fields (Koonce et al. 2011). In short, new educational tactics geared towards increasing overall STEM achievement, addressing social inequality in STEM education, and instilling students with the abilities needed to innovate within STEM fields are of the utmost importance. The present study focuses on one such under-examined approach to improving mathematics educational outcomes: accumulation of fine arts courses.

On a theoretical level, visual and performing arts courses instill critical and creative thinking skills in more efficient and impactful ways than other subjects (Hamblen 1993; Harland et al. 2000). The increasing emphasis on STEAM-or the integration of arts education into STEM subjects - is motivated by this notion insofar as it is thought to help students take more creative and innovative approaches to STEM subjects, and in turn, increase academic innovation and achievement. Despite potential benefits of fine arts for STEM (Catterall 2012; Liao, Motter, and Patton 2016; Slee 2011), the implementation of the No Child Left Behind Act, which financially incentivized STEM outcomes over other subjects, and the Great Recession has led to a decline in arts education funding since the early 2000s, disproportionately impacting high-poverty schools (Harland et al. 2000; Parsad and Spiegelman 2012). This means that the potential positive impacts of arts education are less likely to reach students who would theoretically benefit the most.

Although there is a substantial amount of research focusing on the impact of arts education on overall educational outcomes, research on the impact of arts education on STEM achievement is limited. Some descriptive studies have attempted to answer these 
questions using univariate analysis of national data sets, and some have utilized more advanced statistical analysis of small samples, but none have used advanced methods on robust, nationally representative data (Bequette and Bequette 2012; Ellen, R, and Stéphan 2013; Hetland and Winner 2001; Ludwig, Boyle, and Lindsay 2017). The present study will address this gap in the literature through the use of data on over 20,000 adolescents from the nationally representative High School Longitudinal Study of 2009 (HSLS) to answer the following research questions: Does student accumulation of fine arts courses impact mathematics achievement in high school? Does student socioeconomic status moderate this association? This thesis is directed at answering these questions by first presenting a brief literature review, followed by a description of the data and methods that are utilized, an interpretation of the results, and finally a discussion of the findings. 


\section{LITERATURE REVIEW}

Education, Ideology, and Hegemony

The historical and ideological development of mass education in the US is underpinned by a tension between economic justifications for education, i.e., preparing workers, and democratic justifications, i.e., preparing a well-rounded and critically literate populous prepared to govern themselves (Bowles and Gintis 2011; Hochschild 1996). Spring (1989) contends that the United States has not enacted or implemented a coherent national education policy, but rather a conglomeration that is the product of historical events, political ideology, and special interests. National emphasis on the importance of math and science-and later STEM subjects - over all other subjects is a relatively new phenomenon in the US. He posits that both the Cold War and the Civil Rights Movement led to the development of federal education policy geared towards "rationalized and controlled labor market and the control of social conflict arising from racial discrimination and inequalities in the distribution of income" (Spring 1976:173). Post-Cold War education policy has gradually shifted the education system to value positivist, technical knowledge and vocational training over fostering "cultivated" civic actors. The importance or value placed on STEM subjects over the arts reflects this economic imperative. Because arts education is not perceived by most Americans to contribute greatly to economic competitiveness or to produce productive workers, it is devalued ideologically and among the first subjects to be de-funded when schools are struggling academically or financially. A 2012 report from the Department of Education explained that although the US economy was recovering from the recession, and schools 
were receiving more funding overall, funding for arts education continued to decline (Parsad and Spiegelman 2012). Overall, educational goals shifted from well-rounded or 'holistic' to STEM-focused and vocational.

Apple (1990) asserted that schools serve to maintain hegemonic assumptions, thus rendering societal power relations invisible or left to be understood as "common sense." Schools naturalize the institutional acceptance of positivist knowledge-e.g. 'hard facts,' 'proper formulas,' the unequivocally right and wrong answer, etc. - uncoupling this knowledge from the dynamic human actors who produced and continue to produce it. In other words, school curriculum - both overt and hidden - is constructed socially as the ideological limits of knowledge. Put simply, schools in the US often teach students that the one way of arriving at an answer is the memorization of facts and formulas that are not to be questioned. When these limits are aligned with positivist, objective facts rather than historical, dynamic, and conflict-ridden knowledge production, school produces docile workers, rather than free and critical thinking subjects. STEM curriculum in the US is often taught to this "positivist ideal” (Apple 1990). Students are taught to produce technical knowledge but are not taught alternative explanations, the historical and philosophical development of what they are learning, the relationship between power and knowledge, and the crucial role conflict plays in the development of knowledge (Apple 1990; Foucault 2012). Mathematics and science are especially susceptible to being taught to this positivist ideal because of the emphasis put on an objective and universal framework in which the subjects are often taught. One could argue that although math and science education in the US prepares students to be productive workers, it does not 
necessarily produce critical thinkers - a skill necessary for innovation in STEM-related jobs. Students are often taught to memorize and regurgitate facts and formulas in which there are definitively right and wrong answers, rather than engage with the material critically.

In contrast, arts education is thought to teach critical literacy in much more impactful ways than STEM subjects. Hamblen (1993), for instance, posits that art education encourages students to think in ways that deal "with concepts and percepts and opens the way for multiple systems and forms of knowing and being." Put another way, art education teaches complex ways of thinking and of understanding the world conceptually and experientially. Through the study of aesthetics, composition, identity, semiotics, historical movements, and so on, students are taught ways of thinking that emphasize the relationship between art, themselves, and larger social systems. For these reasons, when paired with math and science education, art education has the potential to provide critical and creative thinking skills essential to students' ability to innovate in STEM fields. STEM education alone might impair students' potential to perform the skill that is the most important in $21^{\star-}$-century labor markets. In sum, contemporary US STEM curriculum might actually undermine the economic imperatives that have motivated its prevalence and preference over other subjects such as the arts.

This cultural orientation toward curriculum and pedagogy may be implicated in the social reproduction of disadvantage (Apple 1990). High-SES students are more likely than socially disadvantaged students to receive STEM curriculum that encourages them to approach the material critically (Darling-Hammond 2000). In this way, the US STEM 
curriculum simultaneously reproduces social inequalities and also compounds them (Hochschild 1996). High-SES students also attend schools that offer more fine arts courses, which may provide more opportunities for them to learn critical thinking skills that can transfer to STEM subjects (Parsad and Spiegelman 2012). Taking these points together, low-SES students are more likely to be exposed to hegemonic curriculum which fosters the passive consumption and memorization of facts, rather than critical thinking skills, such that they stand to experience more benefit from fine arts courses than their high-SES peers. Yet, low-SES students are less likely than high-SES students to have access to fine arts education. Increasing access to fine arts courses for all students, and shifting cultural preferences toward a more holistic curriculum, might help to mitigate these unintended consequences.

From STEM to STEAM: Key Theoretical Assumptions

STEAM education-i.e. science, technology, engineering, art, and mathematics, or the integration of arts and STEM education rather than distinct and separate disciplines - is increasingly perceived as a means of improving STEM achievement and closing achievement gaps within the US (Bequette and Bequette 2012; Robelen 2011). Any argument for the integration of arts education into STEM subjects, however, rests on a key theoretical assumption. Namely, that arts education instills creative and critical thinking skills in ways that are potentially more cognitively impactful and transferrable than other subjects (Bowen 2017; Eisner and Day 2004; Fava 2017; Hamblen 1993; Harland et al. 2000; Pantaleo 2017; Roy 2016; Santín and Torruella 2017). In an 
experimental study, Bowen et al. (2014) show students who were exposed to an art criticism education program demonstrated significantly higher critical thinking skills, skills necessary for innovation, than those who were not.

McFee (1961) asserts that art education encourages students to think in pluralistic and thus more innovative ways, with an emphasis on dialectical thinking, between subjects or concepts explored within the works they created and the world around them. The peer-critique, or "crit," is one common curricular example of this in a high school visual arts context. The crit functions similarly to an exam in other subjects insofar as it serves as an evaluative mechanism and is a curricular requirement adopted by the National Coalition for Core Arts Standards (2019). Students are required to present the artwork they have created and are asked to "defend" it, while the other students and teacher critically analyze how the work is being perceived. In many classrooms, students are encouraged to avoid phrases connoting their idiosyncratic tastes such as "I like it," or "it's really pretty." Rather students are asked to discuss how the work is functioning formally, as well as how the work relates to contemporary political issues, identity, and culture. Students are encouraged to critically analyze the work aesthetically and contextualize its larger societal implications. Students are taught that not only one way of understanding is correct. This curriculum encourages "reflective skepticism," debate, and dialectic thinking which is believed to be transferable to other subjects (Hamblen 1993; McFee 1961; McPeck 2016). Meaning that students should be able to apply, or transfer, such critical thinking skills to science and mathematics courses. 
Based on the theoretical framing presented above, taking fine arts courses might help students to apply more innovative approaches to STEM courses, thus improving academic achievement in those subjects. Meaning that arts education has the potential to provide students with cognitive skills - i.e. critical, reflexive, and creative - that can transfer to STEM subjects and in turn, advantage them in school and into the labor market (Bazler and Van Sickle 2017). This 'transferability' paradigm underpins arguments for STEAM education and motivates much of the research concerned with the integration of arts education into STEM fields as potential interventions. Strong empirical evidence supporting cognitive transfer from arts education to STEM subjects, however, has not been provided in the literature. In other words, whether or not taking arts courses relates to higher achievement in math and science subjects has not been adequately explored.

\section{Cognitive Transfer, SES, and Empirical Evidence}

There are few recent studies examining the relationship between arts course accumulation and STEM outcomes. ${ }^{1}$ There are fewer still that consider the potential moderating effects of student SES. Utilizing the National Educational Longitudinal Study, Catterall (2012) found a significant positive connection between students' exposure to arts education and overall academic success, and that this effect was greater for high poverty students. Similarly, Bowen et al. (2014) found that the positive effects of

\footnotetext{
${ }^{1}$ See Deasy_(2002) for a detailed summary of relevant research prior to 2002.
} 
arts education on students' critical and creative thinking skills were larger for those from disadvantaged backgrounds. This suggests that the prioritization of arts education can help to close gaps in overall academic achievement. However, findings remain mixed when considering positive relationships between arts courses and STEM outcomes more generally. Of the studies investigating the impacts of fine arts on academic achievement, results have been inconsistent; some find arts education benefits overall academic achievement (Catterall 2012; Ludwig et al. 2017), whereas others conclude results are empirically unreliable (Hetland and Winner 2001; Winner and Cooper 2000). Overall, the justification of arts education via the transferability paradigm is hotly contested and results remain mixed (Eisner 1999; Eisner and Day 2004).

More recent research in STEAM education however has been approached from a slightly different frame. First, from a theoretical perspective, the transferability paradigm has been complicated. Instead of considering the value of arts education as a distinct discipline, it is now being considered in how it benefits learning outcomes in other subjects through curricular integration. For example, a chemistry teacher might ask students to sculpt molecular models out of clay. Research suggests that arts integrated interventions (STEAM programs) have some positive impacts on math (Kariuki and Humphrey 2006; Kinney and Forsythe 2005) and science (Kinney and Forsythe 2005) outcomes. Other reports provide evidence that similar interventions have students attitudes towards math (An et al. 2014; Werner 2001), and special reasoning (Taylor and Hutton 2013). These studies, however, focus on STEAM interventions and although justifications for STEAM assume a transfer effect on a theoretical level, they are unable 
to provide evidence of the benefits of arts education, as a finite discipline, on math and science outcomes.

This body of research, focusing on the potential academic benefits of STEAM interventions, rests on the integrative valuation of arts education and is most generally composed of qualitative case studies (Bazler and Van Sickle 2017; Grant and Patterson 2016; Quigley and Herro 2016; Robelen 2011). The overall impact of the STEAM approach on academic achievement is well documented within this body of research but is limited in both validity and generalizability. Furthermore, STEAM approaches are criticized for breaking down student understandings of discipline-specific ways of thinking methodologically (Bequette and Bequette 2012). Justifications for the STEAM approach, however, rests on theoretical assumptions - i.e. potential transfer effects - that have not been grounded within advanced quantitative analyses (Eisner and Day 2004; Hetland and Winner 2001). 


\section{PURPOSE OF THE PRESENT STUDY}

As the importance of innovative approaches to boosting outcomes in and increasing access to STEM education is at the fore of almost every national education debate (Atkinson and Mayo 2010), it is important to examine the theoretical assumptions i.e., that fine arts education teaches critical and creative skills that can be transferred to STEM subjects. Although this study is unable to measure these theoretical mechanismsi.e. critical and creative thinking skills - based on data limitations, it will explore the potential for evidence of cognitive transfer focusing specifically on the impact of fine art course accumulation on mathematics achievement, and further, whether SES moderates this relationship. In addition, the current study will utilize nationally representative data and control on initial levels of mathematics achievement and proficiency, key demographic differences, school-level differences, as well as key out-of-school factors to help rule out spuriousness. The two hypotheses examined are:

H1: Credit accumulation in fine arts courses will relate to a higher likelihood of advancing past Algebra II in high school, accounting for other related differences

H2: This positive relationship will be more pronounced for low-SES students than for their higher-SES peers, net of controls 


\section{DATA AND METHODS}

This study utilizes nationally representative data from the High School Longitudinal Study of 2009 (HSLS), a study administered by the National Center for Education Statistics (NCES). HSLS is focused on examining student trajectories throughout high school, postsecondary education, and into the workforce with a special focus on math and science. The HSLS base-year survey was conducted in fall 2009 with 21,444 9 $9^{\text {th }}$ graders in 944 public and private high schools in the United States. HSLS includes three follow-up waves thus far, which were conducted in 2012, 2013, and 2016. In the base year (Wave 1), NCES also surveyed each students' parents, their math and science teachers, as well as their school administrators and counselors. I use data from both the Wave 1 (2009) and Wave 3 (2013) student surveys, as well as transcript data linked by the NCES in the analysis. Of the 23,415 participants with transcript data (Ingels et al. 2015), I excluded students missing on the dependent variable (math course attainment), resulting in a final analytic sample of $21,870 .^{2}$ Contingent on the variables included in analyses (Radford et al. 2018), I apply the "W3HSTRANS" weight in all analyses. Similar to other data sets with complex survey design (Bollen et al. 2016; West 2016), HSLS does not include level-specific weights that statistical packages require to estimate multilevel models. I rescale the weight to sum to the effective cluster sizes within schools for use in multi-level regression analyses following the recommendations made by statisticians tackling this issue (Carle 2009; Chen, Ping; Chantala, Kim 2014;

\footnotetext{
${ }^{2}$ NCES requires all unweighted frequencies to be rounded to the nearest ten.
} 
Rabe-Hesketh and Anders 2007; West 2016). In addition, I add the data's stratification variables as controls as suggested by Stapleton and Kang (20ㅜㅛㅛ).

I handle missing values on all independent variables using multiple imputation with 5 imputed data sets via the MICE system of chained equations (White, Royston, and Wood 2011).

Advanced Past Algebra II (Transcript Data (2014))

This study examines how credit accumulation in fine arts education relates to whether students advance past Algebra II. Research suggests that advancing past Algebra II is a substantive measure of mathematics achievement, as a strong indicator of postsecondary enrollment, majoring in a STEM field, and college completion (Adelman 2006; Schneider, Swanson, and Riegle-Crumb 1997; Trusty 2002; Trusty and Niles 2003).

Using transcript School Courses for the Exchange of Data (SCED) codes, NCES constructed a mathematics achievement measure. 'SCED is a 5-digit identification coding scheme which captures the subject, title, and the sequence of a course, as well as the level and number of Carnegie units available for the course (Ingels et al. 2015). Students who received any nonzero value for credit hours earned in the highest-level mathematics course in the pre-post-secondary pipeline were placed in that category - e.g., if a student received 1 credit in a trigonometry course and did not earn credit hours in any higher math course, they would be placed in the "Trigonometry" category (Dalton, Ingels, and Fritch 2016). The NCES variable is a 13-point ordinal measure of math course attainment 
ranging from 0 , 'no math,' to 13 , 'AP/IB Calculus. I created a dichotomous indicator by collapsing Algebra II and all hierarchical categories below into a 'no' category, and all categories above Algebra II into an affirmative category.

\section{Credit Accumulation in Fine Arts Education (Transcript Data (2014))}

Course accumulation in fine arts education, the predictor of interest in this study, is measured using a variable constructed by the NCES using student transcript data. This continuous variable captures the amount of Carnegie units earned for completing a course, with one unit representing the completion of a course that meets for one hour, five days per week for one year (Ingels et al. 2015). This measure is categorized based on SCED course identification codes and captures courses designated as visual and/or performing arts courses. Courses were designated as visual and performing arts based on recommendations by the State Education Agency Directors of Arts Education (National Forum on Education Statistics 2014). These categories include dance, theater, music, visual arts, media arts, and other interdisciplinary arts courses.

\section{Socioeconomic Status (Wave 1 (2009) Student Data)}

To explore possible moderation of students' SES on the estimated impact of fine arts credit accumulation on mathematics achievement, I interact a continuous measure of student SES with fine-arts-credit-accumulation. Students' SES composite measures were calculated by the NCES using their parents/guardians' Wave 1 reports of their highest level of education, their occupations, and their total family income (Ingels et al. 2011). 
The NCES used multiple imputation with 5 imputed sets to address missing values on the variables used to compute the composite variable (Ingels et al. 2011).

Student-level Controls (Wave 1 (2009) Data)

I include both highest-level mathematics course taken by $9^{\text {th }}$ grade and students' Wave 1 math test score as control variables to narrow the focus on the estimated impact of fine arts education by accounting for baseline differences in mathematics ability and initial placement. Both factors are highly correlated with end of high school math course attainment and so represent powerful controls. Based on transcript data, NCES measures highest-level math course attained by $9^{\text {th }}$ grade with a 13-point hierarchical scale ranging from 0 , 'No Math,' to 13 , 'AP/IB Calculus.' To more closely align with the math course hierarchy established in the literature (Adelman 2006; Schneider et al. 1997), and based on exploratory analyses on the congruity between math test scores and the NCES categories, I recoded this variable to have six categories: $0=$ No math, $1=$ Lower than Algebra I (combining pre-Algebra, basic math, other math), 2=Algebra I, 3=Geometry, 4=Algebra II, 5=Other advanced math (Trigonometry, Pre-Calculus, Probability and Statistics, and Advanced Placement (AP) / International Baccalaureate (IB) courses other than Calculus), and 6=Calculus (regular and AP/IB calculus). The NCES administered an assessment of students' abilities in mathematics during Wave 1 data collection (first semester of $9^{\text {th }}$ grade). I use the 2009 mathematics assessment theta score which is measured on a continuous scale and provides a "norm-referenced" measurement of 
ability-i.e., an estimation of proficiency relative to the population overall (Ingels et al. 2011).

Students' sex and race are NCES composite measures which impute Wave 1 student reports utilizing school sampling rosters and Wave 1 parent survey data.

Students' reported sex is dummy coded with 1 indicating female and 0 indicating male. I combine 'Hispanic, no race specified' and 'Hispanic, race specified.' In addition, I recode 'American Indian/Alaska Native,' 'Native Hawaiian/Pacific Islander,' and 'More than one race, non-Hispanic' as 'other race' due to small cell sizes.

In addition to individual academic and demographic factors, I control for relevant family characteristics as they might provide an alternative explanation for the first hypothesis. At least one parent has a STEM degree is a dichotomous measure that combines variables measuring whether or not students have a parent that completed at least a bachelor's degree with a STEM major. At least one parent in a STEM field is a second dichotomous variable that captures whether students have a parent with a current or recent occupation in a NCES categorized STEM field.

\section{School Characteristics (Wave 1 (2009) Data)}

I also control for school-level differences with Wave 1 variables describing the student body, teacher and counselor perceptions of teacher expectations, school structure, STEM focus, and academic programming. Student body characteristics are measured in the percent of students at each school that are eligible for free or reduced lunch and English Substantive Learners. Scales averaging Wave 1 reports of counselor perception 
of teacher and administrator expectations (alpha $=0.91)$, math teachers' perception of math teachers' motivation (alpha= 0.91 ), and math and science teachers' perception of teachers' motivation (alpha $=0.91)$, are used to measure teacher motivations and expectations. Some measures were reverse coded to address directionality. The structure of schools is measured using school type (public, Catholic, or other private), region, and urbanicity. To measure relevant academic programming, Wave 1 variables are employed in which administers provided several dichotomous reports of level and type of math offered at their school. These reports were combined to measure math course offerings and ordered from highest to lowest: Up through AP/IB, Up through Calculus but no $\mathrm{AP} / \mathrm{IB}$, No Calculus or AP/IB, and No math offered. A scale was also created to measure the extent to which schools foster a STEM-focused environment (alpha= 0.63$)$ which averaged administrators' reports of whether the school sponsors math and/or science after-school programming, holds math and/or science fairs, and so on. School programming is further measured with the percent of students in AP courses, in special education, repeating $9^{\text {th }}$ grade, in an alternative program, or in a dropout prevention program. The survey items used to construct scales are detailed in the Appendix. 


\section{Analytic Plan}

Descriptive statistics depict the dependent variable, predictor of interest, moderator, and control variables in this nationally representative sample. The averages and proportions in Tables 1 and 2 are adjusted using Stata's survey command to reflect qualities of the population rather than the sample. In addition, descriptive statistics on fine art course accumulation and advancing past Algebra II are stratified by SES tertiles to detect baseline differences in the population estimates. To answer the first research question, I use multilevel random-intercept logistic regression models predicting whether students' advanced past Algebra II with credits earned in fine arts courses. Multilevel models are utilized to account for the clustering of students within schools which violates the assumption of independent errors (Bollen and Brand 2010). Fixed-intercept models would be preferred because they have fewer assumptions (Clarke et al. 2010). I chose random-intercept however because of insufficient variation in SES within schools due to school segregation. As recommended by Clarke et al. (2010 $\underline{10})$, I include school-level controls to increase the likelihood of meeting random-intercept assumptions. The first model estimates the baseline impact of accumulation of fine arts courses on whether students progressed past Algebra II, and controls are entered in the second model.

To investigate the possible moderating effects of SES, a final model includes an interaction term between fine-arts-credit-accumulation and students' SES. To facilitate

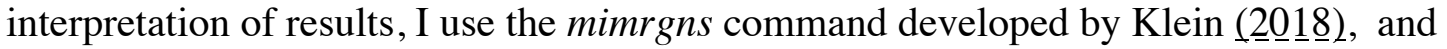

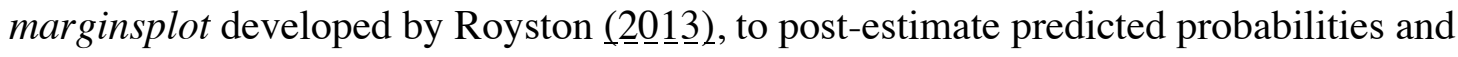
display them graphically. 


\section{RESULTS}

Descriptive statistics are provided in Table 1 . Overall, $54 \%$ of $9^{\text {th}}$-grade students in 2009 advanced past Algebra II by the end of high school. In addition, students accumulated roughly two (1.78) credits in fine arts courses by the time they exited high school. Additionally, students generally fall around the middle of the SES scale (-0.07) with values ranging from -1.93 to 2.88 . Estimated population means, standard errors, ranges, and proportions are provided for all other measures included in regression analysis. $^{3}$

${ }^{3}$ Standard errors for means rather than standard deviations are provided because the means and proportions are adjusted to be population- rather than sample-estimates; see Sribney (2019). 
Table 1, Part 1 of 2: Descriptive Statistics

\begin{tabular}{|c|c|c|c|}
\hline & $\begin{array}{l}\text { Mean or } \\
\text { Proportion }\end{array}$ & (SE) & Range \\
\hline \multicolumn{4}{|l|}{ Dependent Variable: } \\
\hline Advanced past Algebra II $(n=21,870)$ & 0.54 & $(0.01)$ & \\
\hline \multicolumn{4}{|l|}{ Predictor of Interest: } \\
\hline Total credit hours in Fine Arts courses & 1.78 & $(0.04)$ & 0,33 \\
\hline \multicolumn{4}{|l|}{ Moderator: } \\
\hline Socioeconomic status & -0.07 & $(0.02)$ & $-1.93,2.88$ \\
\hline \multicolumn{4}{|l|}{ Individual Controls: } \\
\hline \multicolumn{4}{|l|}{ Race: } \\
\hline White & 0.53 & $(0.01)$ & \\
\hline Black & 0.12 & $(0.01)$ & \\
\hline Hispanic & 0.22 & $(0.01)$ & \\
\hline Asian & 0.04 & $(0.00)$ & \\
\hline Other & 0.09 & $(0.00)$ & \\
\hline Female & 0.50 & $(0.01)$ & \\
\hline \multicolumn{4}{|l|}{ Highest 9 th grade math completed } \\
\hline No math & 0.09 & $(0.01)$ & \\
\hline Lower than Algebra I & 0.08 & $(0.01)$ & \\
\hline Algebra I & 0.57 & $(0.01)$ & \\
\hline Geometry & 0.19 & $(0.01)$ & \\
\hline Algebra II & 0.05 & $(0.00)$ & \\
\hline Other Advanced Math & 0.01 & $(0.00)$ & \\
\hline 9th grade math test score & -0.07 & $(0.02)$ & $-2.58,3.03$ \\
\hline At least one parent has STEM degree & 0.12 & $(0.01)$ & \\
\hline At least one parent has STEM occupation & 0.44 & $(0.01)$ & \\
\hline \multicolumn{4}{|l|}{ School Student Body Demographics Controls: } \\
\hline Percent eligible for free lunch & 39.20 & $(1.18)$ & \\
\hline Percent English language learners & 6.27 & $(0.52)$ & \\
\hline \multicolumn{4}{|l|}{ School Student Body Programming Controls: } \\
\hline Percent in special education & 12.75 & $(0.37)$ & \\
\hline Percent in alternative program & 2.58 & $(0.23)$ & \\
\hline Percent in dropout prevention program & 1.99 & $(0.21)$ & \\
\hline Percent in Advanced Placement courses & 16.12 & $(0.53)$ & \\
\hline Percent repeating grade 9 & 5.13 & $(0.28)$ & \\
\hline
\end{tabular}




\begin{tabular}{|c|c|c|c|}
\hline & $\begin{array}{c}\text { Mean or } \\
\text { proportion }\end{array}$ & (SE) & Range \\
\hline \multicolumn{4}{|l|}{ School Structure Controls: } \\
\hline \multicolumn{4}{|l|}{ School type: } \\
\hline Public & 0.93 & $(0.00)$ & \\
\hline Catholic & 0.04 & $(0.00)$ & \\
\hline Other private & 0.03 & $(0.00)$ & \\
\hline \multicolumn{4}{|l|}{ School urbanicity: } \\
\hline City & 0.32 & $(0.01)$ & \\
\hline Suburb & 0.33 & $(0.01)$ & \\
\hline Town & 0.13 & $(0.01)$ & \\
\hline Rural & 0.23 & $(0.01)$ & \\
\hline \multicolumn{4}{|l|}{ School region: } \\
\hline Northeast & 0.18 & $(0.01)$ & \\
\hline Midwest & 0.22 & $(0.01)$ & \\
\hline South & 0.36 & $(0.01)$ & \\
\hline West & 0.24 & $(0.01)$ & \\
\hline \multicolumn{4}{|l|}{ School math course offerings: ${ }^{a}$} \\
\hline Up through AP/IB & 0.89 & $(0.02)$ & \\
\hline Up through Calculus but no AP/IB & 0.09 & $(0.01)$ & \\
\hline No Calculus or AP/IB & 0.02 & $(0.01)$ & \\
\hline No math offered & 0.01 & $(0.01)$ & \\
\hline School fosters STEM environment & 0.51 & $(0.01)$ & \\
\hline \multicolumn{4}{|l|}{ School Educator Orientation Controls: } \\
\hline Counselor perception of school adult expectations & 2.37 & $(0.07)$ & $0.47,3.00$ \\
\hline $\begin{array}{l}\text { Math teacher's perception of school's math } \\
\text { teachers' motivation }\end{array}$ & 2.20 & $(0.01)$ & $0.25,3.00$ \\
\hline $\begin{array}{l}\text { Math/science teachers' perception of school's } \\
\text { teachers' motivation }\end{array}$ & 2.03 & $(0.01)$ & 0,3 \\
\hline \multicolumn{4}{|c|}{$\begin{array}{l}\text { Notes: These analyses are based on } 21,020 \text { adolescents. Analytic sample sizes are noted next to the dependent } \\
\text { variable. }\end{array}$} \\
\hline
\end{tabular}

Table 2 indicates that students who are in the low-SES-tertile are about half as likely to advance past Algebra II than their peers in the high-SES-tertile, 0.38 and 0.78 respectively. Meaning that high-SES students are much more likely to advance past Algebra II than their low-SES counterparts. Additionally, high-SES students accumulate more art classes on average than low-SES students. Low-SES students average about one 
and a half (1.44) credits in fine arts courses, while high-SES students accumulate about one credit more (2.27). Overall, high-SES students both have a much higher likelihood of advancing past Algebra II and receive about one credit more in fine arts than low-SES students. Standard errors and ranges are also provided.

Table 2: Descriptive Statistics Stratified by SES

\begin{tabular}{|c|c|c|c|c|c|c|}
\hline & \multicolumn{3}{|c|}{ All Students } & \multicolumn{3}{|c|}{ Low-SES } \\
\hline & $\begin{array}{l}\text { Mean or } \\
\text { Proportion }\end{array}$ & (SE) & Range & $\begin{array}{c}\text { Mean or } \\
\text { Proportion }\end{array}$ & (SE) & Range \\
\hline \multicolumn{7}{|l|}{ End-of-High-School Math Achievement } \\
\hline Advanced past Algebra II $(n=21,870)$ & 0.54 & $(0.01)$ & & 0.38 & $(0.02)$ & \\
\hline \multicolumn{7}{|l|}{ Course Acculation in Fine Arts Education } \\
\hline \multirow[t]{3}{*}{ Total credit hours in Fine Arts courses } & 1.78 & $(0.04)$ & 0,33 & 1.44 & $(0.04)$ & 0,14 \\
\hline & \multicolumn{3}{|c|}{ Median-SES } & \multicolumn{3}{|c|}{ High-SES } \\
\hline & $\begin{array}{c}\text { Mean or } \\
\text { Proportion }\end{array}$ & (SE) & Range & $\begin{array}{c}\text { Mean or } \\
\text { Proportion }\end{array}$ & (SE) & Range \\
\hline \multicolumn{7}{|l|}{ End-of-High-School Math Achievement } \\
\hline Advanced past Algebra II $(n=21,870)$ & 0.53 & $(0.01)$ & & 0.78 & $(0.01)$ & \\
\hline \multicolumn{7}{|l|}{ Course Acculation in Fine Arts Education } \\
\hline Total credit hours in Fine Arts courses & 1.78 & $(0.04)$ & 0,14 & 2.27 & $(0.12)$ & 0,33 \\
\hline
\end{tabular}

To understand the independent effects of fine arts education, Table 3 shows log odds from multilevel logistic regression models, with a random-intercept at the school level, predicting students advancing past Algebra II. Model 1 shows that the log odds of advancing past Algebra II increase significantly ( 0.24 , on average) with every one-credit increase in the number of credits accumulated in fine arts courses. After controlling for relevant measures in Model 2, the significant positive estimated effect of fine arts education holds but the magnitude is reduced to 0.15 . These findings support my first 
hypothesis and suggest that credit accumulation in fine arts courses relates to a higher

likelihood of advancing past Algebra II in high school, holding related differences

constant.

Table 3, Part 1 of 2: Log Odds from Multilevel Logistic Regression Models Predicting Advancing Past Algebra II

\begin{tabular}{|c|c|c|c|c|c|c|c|c|c|}
\hline & \multirow{2}{*}{\multicolumn{3}{|c|}{$\frac{\text { Model } 1 \text { - Baseline }}{n=21,870}$}} & \multirow{2}{*}{\multicolumn{3}{|c|}{$\begin{array}{c}\text { Model } 2 \text { - Controls } \\
\mathrm{n}=21,870\end{array}$}} & \multirow{2}{*}{\multicolumn{3}{|c|}{$\frac{\text { Model } 3 \text { - Interaction }}{\mathrm{n}=21,870}$}} \\
\hline & & & & & & & & & \\
\hline & $\mathrm{B}$ & & (SE) & $\mathrm{B}$ & & (SE) & $\mathrm{B}$ & & (SE) \\
\hline \multicolumn{10}{|l|}{ Predictor of Interest: } \\
\hline Total credit hours in Fine Arts courses & 0.24 & $* * *$ & $(0.14)$ & 0.15 & $* * *$ & $(0.02)$ & 0.15 & $* * *$ & $(0.01)$ \\
\hline \multicolumn{10}{|l|}{ Moderator: } \\
\hline Socioeconomic status & & & & 0.45 & $* * *$ & $(0.04)$ & 0.57 & $* * *$ & $(0.05)$ \\
\hline Socioeconomic status\#total credit hours in Fine Arts & & & & & & & -0.07 & $* * *$ & $(0.02)$ \\
\hline \multicolumn{10}{|l|}{ Controls: } \\
\hline \multicolumn{10}{|l|}{ Race: } \\
\hline White (ref) & & & & - & & - & - & & - \\
\hline Black & & & & 0.15 & + & $(0.08)$ & 0.15 & + & $(0.08)$ \\
\hline Hispanic & & & & -0.06 & & $(0.07)$ & -0.05 & & $(0.07)$ \\
\hline Asian & & & & 0.52 & $* * *$ & $(0.14)$ & 0.52 & $* * *$ & $(0.14)$ \\
\hline Other & & & & -0.13 & + & $(0.08)$ & -0.13 & + & $(0.08)$ \\
\hline Female & & & & 0.27 & $* * *$ & $(0.04)$ & 0.27 & $* * *$ & $(0.04)$ \\
\hline \multicolumn{10}{|l|}{ Highest 9th grade math course completed: } \\
\hline No math (ref) & & & & - & & - & - & & - \\
\hline Lower than Algebra I & & & & -0.63 & $* * *$ & $(0.11)$ & -0.63 & $* * *$ & $(0.11)$ \\
\hline Algebra I & & & & -0.10 & & $(0.08)$ & -0.11 & & $(0.08)$ \\
\hline Geometry & & & & 1.32 & $* * *$ & $(0.11)$ & 1.32 & $* * *$ & $(0.11)$ \\
\hline Algebra II & & & & 0.70 & $* * *$ & $(0.14)$ & 0.70 & $* * *$ & $(0.14)$ \\
\hline Other Advanced Math & & & & 0.97 & $* *$ & $(0.29)$ & 0.97 & $* *$ & $(0.30)$ \\
\hline 9th grade math test score & & & & 0.98 & $* * *$ & $(0.03)$ & 0.97 & $* * *$ & $(0.03)$ \\
\hline At least one parent has STEM degree & & & & 0.30 & $*$ & $(0.10)$ & 0.30 & $*$ & $(0.10)$ \\
\hline At least one parent has STEM occupation & & & & -0.15 & $*$ & $(0.05)$ & -0.14 & $*$ & $(0.05)$ \\
\hline Percent eligible for free lunch & & & & 0.01 & + & $(0.00)$ & 0.01 & + & $(0.00)$ \\
\hline Percent English language learners & & & & -0.01 & $*$ & $(0.01)$ & -0.01 & $*$ & $(0.01)$ \\
\hline Percent in special education & & & & 0.00 & & $(0.01)$ & 0.00 & & $(0.01)$ \\
\hline Percent in alternative program & & & & -0.01 & & $(0.01)$ & -0.01 & & $(0.01)$ \\
\hline Percent in dropout prevention program & & & & -0.01 & & $(0.01)$ & -0.01 & & $(0.01)$ \\
\hline Percent in Advanced Placement courses & & & & 0.01 & + & $(0.00)$ & 0.01 & + & $(0.00)$ \\
\hline Percent repeating grade 9 & & & & 0.00 & & $(0.01)$ & 0.00 & & $(0.01)$ \\
\hline
\end{tabular}

$+p<0.1,{ }^{*} p<0.05,{ }^{* *} p<0.01,{ }^{* * *} p<0.001$ 
Table 3, Part 2 of 2: Log Odds from Multilevel Logistic Regression Models Predicting Advancing Past Algebra II

\begin{tabular}{|c|c|c|c|c|c|c|c|c|}
\hline & \multirow{2}{*}{\multicolumn{2}{|c|}{$\frac{\text { Model } 1 \text { - Baseline }}{n=21,870}$}} & \multirow{2}{*}{\multicolumn{3}{|c|}{$\begin{array}{c}\text { Model } 2 \text { - Controls } \\
n=21,870\end{array}$}} & \multirow{2}{*}{\multicolumn{3}{|c|}{$\frac{\text { Model } 3 \text { - Interaction }}{n=21,870}$}} \\
\hline & & & & & & & & \\
\hline & $\mathrm{B}$ & (SE) & $\mathrm{B}$ & & (SE) & $\mathrm{B}$ & & (SE) \\
\hline \multicolumn{9}{|l|}{ School type: } \\
\hline Public (ref) & - & - & - & & - & & & \\
\hline Catholic & & & 1.12 & $* * *$ & $(0.20)$ & 1.11 & $* * *$ & $(0.20)$ \\
\hline Other private & & & 0.52 & $*$ & $(0.23)$ & 0.54 & $*$ & $(0.23)$ \\
\hline \multicolumn{9}{|l|}{ School urbanicity: } \\
\hline City (ref) & - & - & - & & - & - & & - \\
\hline Suburb & & & 0.04 & & $(0.11)$ & 0.04 & & $(0.12)$ \\
\hline Town & & & -0.19 & & $(0.17)$ & -0.19 & & $(0.17)$ \\
\hline Rural & & & -0.13 & & $(0.13)$ & -0.13 & & $(0.13)$ \\
\hline \multicolumn{9}{|l|}{ School region: } \\
\hline Northeast (ref) & - & - & - & & - & - & & - \\
\hline Midwest & & & -0.31 & $*$ & $(0.13)$ & -0.31 & $*$ & $(0.13)$ \\
\hline South & & & 0.04 & & $(0.13)$ & 0.04 & & $(0.13)$ \\
\hline West & & & -0.56 & $* * *$ & $(0.15)$ & -0.57 & $* * *$ & $(0.15)$ \\
\hline \multicolumn{9}{|l|}{ School math course offerings: } \\
\hline Up through AP/IB (ref) & & & - & & - & - & & - \\
\hline Up through Calculus but no AP/IB & & & -0.08 & & $(0.14)$ & -0.09 & & $(0.14)$ \\
\hline No Calculus or AP/IB & & & -0.66 & & $(0.47)$ & -0.66 & & $(0.47)$ \\
\hline No math offered & & & -0.30 & & $(0.39)$ & -0.30 & & $(0.39)$ \\
\hline School fosters STEM environment & & & 0.03 & & $(0.17)$ & 0.03 & & $(0.17)$ \\
\hline Counselor perception of school adult expe & ctations & & 0.17 & & $(0.12)$ & 0.17 & & $(0.12)$ \\
\hline $\begin{array}{l}\text { Math teacher's perception of school's ma } \\
\text { teachers' motivation }\end{array}$ & & & 0.07 & & $(0.09)$ & 0.07 & & $(0.09)$ \\
\hline $\begin{array}{l}\text { Math/science teachers' perception of sch } \\
\text { teachers' motivation }\end{array}$ & ol's & & 0.05 & & $(0.09)$ & 0.05 & & $(0.09)$ \\
\hline
\end{tabular}

To explore whether SES moderates the impact of fine arts education on mathematics course attainment, an interaction is included in a third model in Table 3 . In Model 3, the main effect of credit accumulation in fine arts coursework remains positive and statistically significant $(0.15$, on average $)$, controlling for other differences. In the main effect of SES, Model 3 indicates that a higher SES significantly increases the log odds of a student advancing past Algebra II ( 0.57 , on average) for students with 0 arts courses. The interaction between these two variables is negative $(-0.07$, on average $)$ and statistically significant. For every unit change in the number of fine arts credits 
accumulated, the slope of SES vs. advancing past Algebra II decreases by 0.07 . This suggests higher-SES students receive less benefit from fine arts education than lowerSES students. These results are presented graphically in Figure 1 to facilitate interpretation.

Figure 1 shows a graphical representation of predicted probabilities of advancing past Algebra II differentiated by credits in fine arts courses and student SES, with SES partitioned at the $10^{\mathrm{m}}$ (lowest SES), 50" (median SES), and 90" (highest SES) percentiles. Consistent with results from Table 3, the predicted probability of advancing past Algebra II generally increases with increasing credits in fine arts courses. Figure 1 demonstrates that the probability of advanced math course-taking is modestly differentiated by credit accumulation in fine arts courses for the highest-SES students. The steeper slopes of the lines show the benefit of credit accumulation in fine arts courses is significantly greater however for lower-SES students. Among students with no credits in fine arts coursework, there is an approximately 20 percentage-point difference in the predicted probability of advancing past Algebra II between the lowest- and highest-SES students. In contrast, for students who accumulated eight credits in fine arts courses, there is a roughly 0.5 percentage-point gap between the lowest- and the highest-SES students. In other words, when considering the likelihood of students advancing past Algebra II in high school, student accumulation of high levels of fine art credits virtually closes gaps due to unequal SES. This supports my second hypothesis that the positive relationship between accumulation of fine arts credits is more pronounced for low-SES students than for their higher-SES peers, net of controls. 
Figure 1: Predicted Probabilities of Advancing Past Algebra II Depending on Credits in Fine Arts and Socioeconomic Status

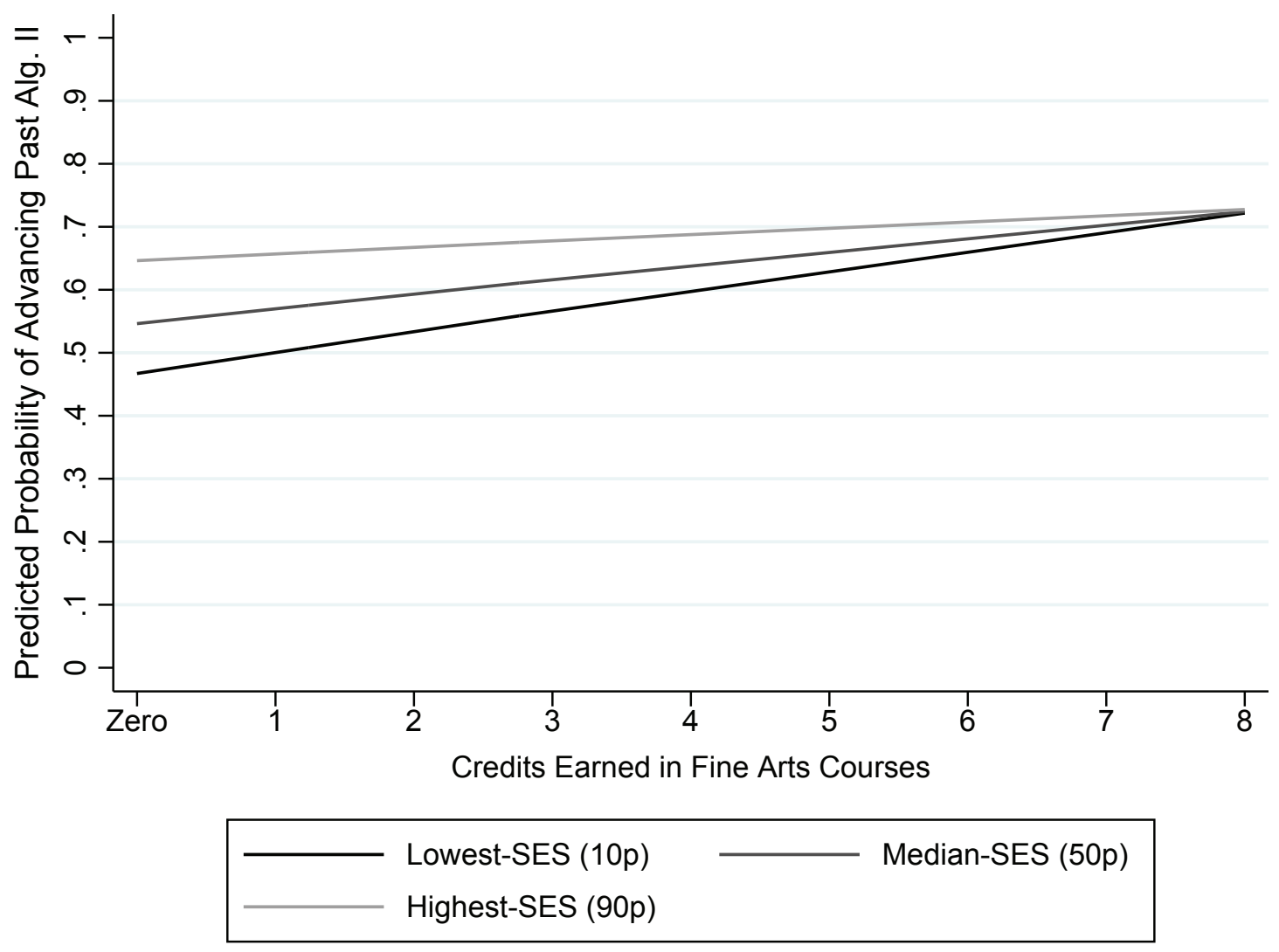

Note: predicted probabilities were estimated from Model 3 in Table 3 


\section{DISCUSSION}

Scholars have suggested that fine arts education teaches students creative and critical thinking skills that, based on cognitive transferability theory, can be applied to other subjects such as STEM. However, there has been very little research with the goal of testing these assumptions using advanced quantitative methods and less still that have utilized robust, nationally representative data sets. Research also suggests that the inclusion of arts education can help to narrow gaps in STEM achievement based on SES. This study improves understanding of the impacts of fine arts education on math achievement in high school through the use of multilevel logistic regression modeling, nationally representative data, and long-standing lines of sociological and educational theory. The results of this study suggest that taking fine arts courses increases the likelihood that students will advance past Algebra II in high school. More importantly, this association is much more pronounced for lower-SES students. The US continues to prioritize STEM achievement overall as well as closing achievement gaps based on unequal SES among students. This study suggests that further investment in STEM education alone might not be an optimal solution and provides evidence that, alongside STEM education, fine arts education can contribute to these educational goals. Furthermore, it provides a strong case that fine arts education should be prioritized in low-SES schools during a historical period in which fine arts programming is more likely to be eliminated in those very same schools.

Hetland and Winner (2001), among others, argue that mixed results in the literature point to problematic motivations for research concerned with the utility of arts 
education. They conclude that the value of arts education should not be evaluated based on the ways arts might positively impact other subjects, but rather on the fact that the arts are an important part of culture "and an education without them is an impoverished education leading to an impoverished society" (Hetland and Winner 2001:5). Eisner (1999) corroborates this sentiment but emphasizes that most quantitative analyses of arts education's impact on academic achievement are similar in that they employ problematic research designs and/or nonrepresentational samples. Meaning that, although the justification of arts education should not have to rely on proving its academic utility within other subjects alone, research in this area is often fundamentally flawed. Additionally, this argument ignores the need for low-income schools to justify programmatic spending based on key deliverables that are often STEM achievement outcomes.

Some important limitations of the present study are worth noting. These findings provide only modest support for cognitive transferability theory. Compared to their peers, students who take fine arts courses are more likely to advance past Algebra II. However, because HSLS does not provide an accurate measure for creative and/or critical thinking skills, the actual mechanism, it cannot be claimed that this is due to cognitive transfer. Providing strong evidence of transfer would require mediation analysis and a strong longitudinal measure of critical and creative thinking skills. It could be, for instance, that students who take many arts courses are more socially integrated which is positively associated with better mathematics outcomes (Reynolds et al. 2017). The inability to measure whether teachers are, and to what extent they are, integrating arts education into 
STEM curriculum (STEAM approach) provides a second limitation of this study. It could be that this is more likely to happen in higher-SES schools, which would help explain some of the moderation effects. Additionally, it is likely that art courses are taught inconsistently across schools. Meaning that, credit accumulation in fine arts is not necessary a consistent measure across schools. Another limitation of note is that some students in the sample may have taken arts courses after completing their math course requirements, meaning that a causal argument cannot be made. Finally, the findings presented could be due to unmeasured factors. It could be that there is a tendency for students who take many arts and math courses to take certain types of other courses or activities that positively influence their likelihood to advance past algebra II.

Overall, this study provides support for the inclusion of fine arts education in STEM education debates. If Americans are committed to improving access to and achievement in STEM subjects, it is important to consider a wide range of pedagogical approaches and interventions. This research suggests that fine arts education might be one such approach. In the midst of sweeping neoliberal economic policy and globalized markets, economic competitiveness and viability rely on innovative approaches to the STEM fields. Educationally speaking and especially since the Cold War, students seem to be being trained as docile workers, rather than critically literate, innovative scientists and engineers. More importantly, social systems place substantial limitations on entering STEM fields for low-SES Americans. This research suggests that the inclusion of fine arts education in high school, and potentially a STEAM approach, may be the intervention the US has been seeking for some time. At the same time, arts education 
faces an unprecedented period of chronic underfunding in the U.S. with underserved districts being hit the hardest.

Future research should explore the impact of taking fine arts courses on achievement gaps among students that are disadvantaged or underrepresented in STEM in different ways. For example, researchers might investigate whether race, sex, or being labeled with a learning disability might moderate the impact of fine art education on STEM performance. In addition, other predictors of STEM field participation should be examined such as STEM GPA, and highest level in physics courses. Finally, locating accurate measures for creative and critical thinking skills would strengthen any argument for cognitive transfer from fine arts courses to STEM subjects. 


\section{REFERENCES}

Adelman, Clifford. 2006. The Toolbox Revisited: Paths to Degree Completion From High School Through College. ED Pubs, P.

An, Song A., Daniel A. Tillman, Rachel Boren, and Junjun Wang. 2014. "Fostering Elementary Students' Mathematics Disposition through Music-Mathematics Integrated Lessons.” International Journal for Mathematics Teaching and Learning 15(3):1-19.

Apple, Michael W. 1990. Ideology and Curriculum. Psychology Press.

Atkinson, Robert and Merrilea Mayo. 2010. Refueling the U.S. Innovation Economy: Fresh Approaches to Science, Technology, Engineering and Mathematics (STEM) Education. SSRN Scholarly Paper. ID 1722822. Rochester, NY: Social Science Research Network.

Bazler, Judith and Meta Van Sickle. 2017. Cases on STEAM Education in Practice. IGI Global.

Bequette, James W. and Marjorie Bullitt Bequette. 2012. “A Place for ART and DESIGN Education in the STEM Conversation." Art Education; Reston 65(2):40-47.

Blums, Angela, Jay Belsky, Kevin Grimm, and Zhe Chen. 2017. "Building Links Between Early Socioeconomic Status, Cognitive Ability, and Math and Science Achievement." Journal of Cognition and Development 18(1):16-40. 
Bollen, Kenneth A., Paul P. Biemer, Alan F. Karr, Stephen Tueller, and Marcus E. Berzofsky. 2016. “Are Survey Weights Needed? A Review of Diagnostic Tests in Regression Analysis.” Annual Review of Statistics and Its Application 3(1):37592.

Bollen, Kenneth A. and Jennie E. Brand. 2010. “A General Panel Model with Random and Fixed Effects: A Structural Equations Approach.” Social Forces 89(1):1-34.

Bowen, Daniel H., Jay P. Greene, and Brian Kisida. 2014. "Learning to Think Critically: A Visual Art Experiment.” Educational Researcher 43(1):37-44.

Bowen, Tracey. 2017. “Assessing Visual Literacy: A Case Study of Developing a Rubric for Identifying and Applying Criteria to Undergraduate Student Learning." Teaching in Higher Education 22(6):705-19.

Bowles, Samuel and Herbert Gintis. 2011. Schooling in Capitalist America: Educational Reform and the Contradictions of Economic Life. Haymarket Books.

Carle, Adam C. 2009. "Fitting Multilevel Models in Complex Survey Data with Design Weights: Recommendations.” BMC Medical Research Methodology 9(1):49.

Catterall, James S. 2012. "The Arts and Achievement in At-Risk Youth: Findings from Four Longitudinal Studies. Research Report\# 55." National Endowment for the Arts. 
Chen, Ping; Chantala, Kim. 2014. "Guidelines for Analyzing Add Health Data." Carolina Digital Repository.

Clarke, Paul, Claire Crawford, Fiona Steele, and Anna Vignoles. 2010. The Choice Between Fixed and Random Effects Models: Some Considerations For Educational Research (DoQSS Working Paper No. 10-10. London, UK: Department of Quantitiative Social Science, Institute of Education, University of London.

Dalton, Ben, Steven J. Ingels, and Laura Fritch. 2016. High School Longitudinal Study of 2009 (HSLS:09). 2013 Update and High School Transcript Study: A First Look at Fall 2009 Ninth-Graders in 2013. (NCES 2015-037rev). National Center for Education Statistics.

Darling-Hammond, Linda. 2000. “Teacher Quality and Student Achievement.” Education Policy Analysis Archives 8(0):1.

Deasy, Richard J. 2002. Critical Links: Learning in the Arts and Student Academic and Social Development. Arts Education Partnership, One Massachusetts Ave.

DeSilver, Drew. 2017. “U.S. Students' Academic Achievement Still Lags That of Their Peers in Many Other Countries.” Pew Research Center. Retrieved December 7, 2017 (http://www.pewresearch.org/fact-tank/2017/02/15/u-s-studentsinternationally-math-science/). 
Eisner, Elliot W. 1999. "Does Experience in the Arts Boost Academic Achievement?" The Clearing House; Washington 72(3):143-49.

Eisner, Elliot W. and Michael D. Day. 2004. Handbook of Research and Policy in Art Education. Routledge.

Ellen, Winner, Goldstein Thalia R, and Vincent-Lancrin Stéphan. 2013. Art for Art's Sake? The Impact of Arts Education: The Impact of Arts Education. OECD Publishing.

Fava, Michelle. 2017. "Drawing Analogies to Deepen Learning." International Journal of Art \& Design Education 36(3):315-24.

Foucault, Michel. 2012. Discipline and Punish: The Birth of the Prison. Knopf Doubleday Publishing Group.

Gonzalez, Heather B. and Jeffrey J. Kuenzi. 2012. “Science, Technology, Engineering, and Mathematics (STEM) Education: A Primer." Congressional Research Service, Library of Congress.

Grant, Jacqualine and Delaney Patterson. 2016. "Innovative Arts Programs Require Innovative Partnerships: A Case Study of STEAM Partnering between an Art Gallery and a Natural History Museum.” The Clearing House; Washington 89(45):144. 
Hamblen, Karen A. 1993. “Theories and Research That Support Art Instruction for Instrumental Outcomes.” Theory Into Practice 32(4):191.

Harland, John, Kay Kinder, Pippa Lord, Alison Stott, Ian Schagen, Jo Haynes, Linda Cusworth, Richard White, and Riana Paola. 2000. "Arts Education in Secondary Schools: Effects and Effectiveness.” Slough: NFER 566.

Hetland, Lois and Ellen Winner. 2001. "The Arts and Academic Achievement: What the Evidence Shows.” Arts Education Policy Review 102(5):3.

Hochschild, Jennifer L. 1996. Facing Up to the American Dream: Race, Class, and the Soul of the Nation. Princeton University Press.

Ingels, Steven J., Daniel J. Pratt, Deborah R. Herget, Laura J. Burns, Jill A. Dever, Randolph Ottem, James E. Rogers, Ying Jin, and Steve Leinwand. 2011. High School Longitudinal Study of 2009 (HSLS:09): Base-Year Data File Documentation. NCES 2011-328. National Center for Education Statistics.

Ingels, Steven, Daniel Pratt, Deborah Herget, Michael Bryan, Laura Fritch, Randolph Ottem, James Rogers, and David Wilson. 2015. "High School Longitudinal Study of 2009 (HSLS:09) 2013 Update and High School Transcripts Data File Documentation.” Retrieved February 18, 2019 (https://nces.ed.gov/pubsearch/pubsinfo.asp?pubid=2015036).

Kariuki, Patrick N. and Steven G. Humphrey. 2006. The Effects of Drama on the Performance of At-Risk Elementary Math Students. 
Kinney, Daryl W. and Jere L. Forsythe. 2005. "The Effects of the Arts IMPACT Curriculum upon Student Performance on the Ohio Fourth-Grade Proficiency Test." Bulletin of the Council for Research in Music Education (164):35-48.

Klein, Daniel. 2018. "MIMRGNS: Stata Module to Run Margins after Mi Estimate.” Boston College.

Koonce, David A., Jie Zhou, Cynthia D. Anderson, Dyah A. Hening, and Valerie Martin Conley. 2011. "What Is STEM?" in American Society for Engineering Education.

Liao, Christine, Jennifer L. Motter, and Ryan M. Patton. 2016. “Tech-Savvy Girls : Learning 21st-Century Skills through STEAM Digital Artmaking.” Art Education 69(4):29-35.

Ludwig, Meredith J., Andrea Boyle, and Jim Lindsay. 2017. "Review of Evidence: Arts Integration Research Through the Lens of the Every Student Succeeds Act.” American Institutes for Research 100.

McFee, June King. 1961. Preparation for Art. Not Stated edition. Wadsworth Publishing Company, Inc.

McPeck, John E. 2016. Critical Thinking and Education. Routledge.

Melguizo, Tatiana and Gregory C. Wolniak. 2012. "The Earnings Benefits of Majoring in STEM Fields Among High Achieving Minority Students." Research in Higher Education 53(4):383-405. 
National Coalition for Core Arts Standards. 2019. "The National Core Arts Standards: A Conceptual Framework for Arts Learning.” Retrieved April 22, 2019 (https://www.nationalartsstandards.org/content/national-core-arts-standards).

National Forum on Education Statistics. 2014. Forum Guide to School Courses for the Exchange of Data (SCED) Classification System. (NFES 2014-802). Washington, DC: National Center for Education Statistics: U.S. Department of Education.

Pantaleo, Sylvia. 2017. “Critical Thinking and Young Children's Exploration of Picturebook Artwork." Language and Education 31(2):152-68.

Parsad, Basmat and Maura Spiegelman. 2012. Arts Education in Public Elementary and Secondary Schools: 1999-2000 and 2009-10. NCES 2012-014. National Center for Education Statistics.

Quigley, Cassie F. and Dani Herro. 2016. “'Finding the Joy in the Unknown': Implementation of STEAM Teaching Practices in Middle School Science and Math Classrooms." Journal of Science Education and Technology 25(3):410-26.

Rabe-Hesketh, Sophia and Skrondal Anders. 2007. "Multilevel Modeling of Complex Survey Data.” Marina del Rey, CA.

Radford, Alexandria Walton, Laura Burns Fritch, Katherine Leu, and Michael Duprey. 2018. High School Longitudinal Study of 2009 (HSLS:09) Second Follow-Up: A First Look at Fall 2009 Ninth-Graders in 2016. NCES 2018-139. National Center for Education Statistics. 
Reynolds, Katherine J., Eunro Lee, Isobel Turner, David Bromhead, and Emina Subasic. 2017. "How Does School Climate Impact Academic Achievement? An Examination of Social Identity Processes." School Psychology International 38(1):78-97.

Robelen, Erik W. 2011. "Building STEAM: Blending the Arts With STEM Subjects." Education Week 31(13):8-9.

Roy, Ken. 2016. "Safety Picks Up 'STEAM."' Science and Children; Washington 53(6):28-29.

Royston, Patrick. 2013. "Marginscontplot: Plotting the Marginal Effects of Continuous Predictors." Stata Journal 13(3):510-27.

Santín, Mercè Fernández and Maria Feliu Torruella. 2017. "Reggio Emilia: An Essential Tool to Develop Critical Thinking in Early Childhood.” Journal of New Approaches in Educational Research 6(1):50-56.

Schneider, Barbara, Christopher B. Swanson, and Catherine Riegle-Crumb. 1997. “Opportunities For Learning: Course Sequences and Positional Advantages.” Social Psychology of Education 2(1):25-53.

Slee, Roger. 2011. The Irregular School: Exclusion, Schooling and Inclusive Education. Taylor \& Francis. 
Spring, Joel H. 1989. The Sorting Machine Revisited: National Educational Policy since 1945. Updated ed. New York: Longman.

Sribney, William. 2019. “Why Doesn't Summarize Accept Pweights?” Stata: Resources and Support.

Stapleton, Laura M. and Yoonjeong Kang. 2018. "Design Effects of Multilevel Estimates From National Probability Samples.” Sociological Methods \& Research 47(3):430-57.

Taylor, Holly A. and Allyson Hutton. 2013. “Think3d!: Training Spatial Thinking Fundamental to STEM Education.” Cognition and Instruction 31(4):434-55.

Trusty, Jerry. 2002. "Effects of High School Course-Taking and Other Variables on Choice of Science and Mathematics College Majors.” Journal of Counseling \& Development 80(4):464-74.

Trusty, Jerry and Spencer G. Niles. 2003. "High-School Math Courses and Completion of the Bachelor's Degree." Professional School Counseling 7(2):99-107.

US Department of Education. 2017. "Science, Technology, Engineering and Math: Education for Global Leadership.” Retrieved December 4, 2017 (https://www.ed.gov/stem).

Werner, Linnette. 2001. Changing Student Attitudes Toward Math: Using Dance to Teach Math. Report. Center for Applied Research and Educational Improvement. 
West, Brady T. 2016. "Fitting Weighted Multilevel Models to Complex Sample Survey Data in SAS: A Case Study." in Michigan SAS Users Group. Ann Arbor, MI.

White, Ian R., Patrick Royston, and Angela M. Wood. 2011. "Multiple Imputation Using Chained Equations: Issues and Guidance for Practice." Statistics in Medicine 30(4):377-99.

Winner, Ellen and Monica Cooper. 2000. "Mute Those Claims: No Evidence (Yet) for a Causal Link between Arts Study and Academic Achievement.” Journal of Aesthetic Education 34(3/4):11-75. 


\title{
APENDIX: SURVEY ITEMS USED TO CONSTRUCT SCALES
}

\author{
School Fosters STEM Environment (alpha=0.63)
}

$$
(0=N o, 1=\text { Yes })
$$

- Holds math or science fairs/workshops/competitions

- Partners $\mathrm{w} /$ college/university that offers math/science summer program

- Sponsors a math or science after-school program

- Pairs students with mentors in math or science

- Brings in guest speakers to talk about math or science

- Takes students on math- or science-relevant field trips

- Tells students about math/science contests/websites/blogs/other programs

- Partners with MESA or a similar enrichment-model program

- Requires teacher prof development in how students learn math/science

\section{Counselor Perception of School Staff Expectations (alpha $=0.91$ )}

○ Teachers in this school set high standards for teaching

- Teachers in this school set high standards for students' learning

- Teachers in this school believe all students can do well

- Teachers in this school work hard to make sure all students learn

- Teachers in this school have given up on some students

- Teachers in this school care only about smart students

- Teachers in this school expect very little from students

- Counselors in this school set high standards for students' learning

- Counselors in this school believe all students can do well

- Counselors in this school work hard to make sure all students learn

- Counselors in this school have given up on some students

- Counselors in this school care only about smart students

- Counselors in this school expect very little from students

- Principal in this school sets high standards for students' learning

- Principal in this school believes all students can do well

- Principal in this school works hard to make sure all students learn

- Principal in this school has given up on some students

- Principal in this school cares only about smart students

- Principal in this school expects very little from students

Math Teacher's Perception of School's Math Teachers' Motivation (alpha=0.91)

○ Math teachers in this department share ideas on teaching

- Math teachers in department discuss what was learned at workshop/conference

- Math teachers in this department share and discuss student work

- Math teachers in this department discuss lessons that were not successful

- Math teachers in this department discuss beliefs about teaching/learning

- Math teachers in department share research on effective teaching methods

- Math teachers in department share research on ELL instructional practices

- Math teachers in department explore approaches for underperforming students 
- Math teachers in department coordinate course content with other teachers

- Math teachers in department are effective at teaching students in math

- Math teachers in this department provide support to new teachers

- Math teachers are supported/encouraged by math department's chair

- Math teachers in this school set high standards for teaching

- Math teachers in the school set high standards for students' learning

- Math teachers in this school believe all students can do well

- Math teachers in this school make goals clear to students

- Math teachers in the school work hard to make sure all students learn

- Math teachers in this school have given up on some students (reverse-coded)

- Math teachers in this school care only about smart students (reverse-coded)

- Math teachers in this school expect very little from students (reverse-coded) Math/Science Teachers' Perception of School's Teachers' Motivation (alpha=0.87) Reports on each survey item from both of each student's $9^{\text {th }}$ grade math and science teacher:

○ Teachers at this school help maintain discipline in the entire school

- Teachers at this school take responsibility for improving the school

- Teachers at this school set high standards for themselves

- Teachers at school feel responsible for developing student self-control

- Teachers at school feel responsible for helping each other do their best

- Teachers at this school feel responsible that all students learn

- Teachers at school feel responsible when students in this school fail 